\title{
KORELASI ANTARA KADAR HbA1C DENGAN LAJU FILTRASI GLOMERULUS (LFG) PADA PASIEN DIABETES MELITUS
}

\author{
Retno Martini Widhyasih ${ }^{1^{*}}$, Ria Nur Puspa Sari ${ }^{1}$, Bagya Mujianto ${ }^{1}$ \\ 1 Jurusan Teknologi Laboratorium Medis, Poltekkes Kemenkes Jakarta III, \\ Jawa Barat, Indonesia \\ e-Mail: retnomartiniw@gmail.com
}

\begin{abstract}
Diabetes mellitus (DM) is a metabolic disorder characterized by prolonged hyperglycemia with a risk of complications in the kidney. Glycemic control can be monitored by means of an HbA1C test. Poor glycemic control can lead to decreased kidney function which can be assessed from the glomerular filtration rate (GFR). GFR is measured using serum creatinine levels using the equation Modification of Diet in Renal Disease (MDRD). This study aims to determine the correlation between HbA1c levels and GFR in DM patients. The research method was observational analytic with cross sectional design on 90 medical records of DM patients in 2019 at Budhi Asih Hospital, which carried out HbA1c and serum creatinine tests as the basis for calculating GFR. Data analysis used Spearman's correlation test with a $95 \% \mathrm{Cl}(a=0.05)$. The results showed that the average HbA1c level was 7.9\%, meaning that most patients had bad $\mathrm{HbA1c}$ levels and the average GFR result was $60 \mathrm{~mL} / \mathrm{min} / 1.73 \mathrm{~m}^{2}$, meaning that most patients had an GFR value $<90 \mathrm{~mL} / \mathrm{min} / 1.73 \mathrm{~m}^{2}$ and indicates a disturbance in renal function. The results of Spearman's correlation show a negative direction $(r)$ of -0.396 . It can be concluded that the higher the HbA1c level, the smaller the GFR value so that DM patients must carry out regular glycemic control to prevent a decrease in kidney function which can lead to complications.
\end{abstract}

Keywords: HbA1c, GFR, Diabetes mellitus

\begin{abstract}
Abstrak
Diabetes Melitus (DM) merupakan kelainan metabolik dengan karakteristik hiperglikemia berkepanjangan dengan risiko komplikasi pada ginjal. Kontrol glikemik dapat dipantau dengan pemeriksaan HbA1c. Kontrol glikemik yang buruk dapat menyebabkan penurunan fungsi ginjal yang dapat dinilai dari laju filtrasi glomerulus (LFG). LFG diukur menggunakan kadar kreatinin serum dengan menggunakan persamaan Modification of Diet in Renal Disease (MDRD). Penelitian ini bertujuan mengetahui korelasi antara kadar HbA1c dengan LFG pada pasien DM. Metode penelitian secara observasional analitik dengan disain cross sectional terhadap 90 data rekam medis pasien DM tahun 2019 di RSUD Budhi Asih, yang melakukan pemeriksaan HbA1C dan kreatinin serum sebagai dasar perhitungan LFG. Analisis data dengan uji korelasi Spearman's dengan $\mathrm{Cl}$ 95\% $(\mathrm{a}=0,05)$. Hasil penelitian didapatkan rata-rata kadar $\mathrm{HbA} 1 \mathrm{C}$ adalah 7,9\% artinya sebagian besar pasien memiliki kadar HbA1c yang buruk dan hasil rata-rata LFG adalah $60 \mathrm{~mL} / \mathrm{min} / 1,73 \mathrm{~m}^{2}$ artinya sebagian besar pasien memiliki nilai $\mathrm{LFG}<90 \mathrm{~mL} / \mathrm{min} / 1,73 \mathrm{~m}^{2}$ dan mengindikasikan adanya gangguan pada fungsi ginjal. Hasil korelasi Spearman's menunjukkan arah negatif ( $r$ ) sebesar -0,396. Dapat disimpulkan bahwa semakin tinggi kadar HbA1c maka semakin kecil nilai LFG sehingga pasien DM harus melakukan kontrol glikemik secara rutin guna mencegah terjadinya penurunan fungsi ginjal yang dapat mengarah pada kejadian komplikasi.
\end{abstract}

Kata kunci: HbA1c, LFG, Diabetes melitus 


\section{PENDAHULUAN}

Data yang dipublikasikan International Diabetes Federation (IDF) tahun 2015 memberikan gambaran jumlah penyandang Diabetes Melitus (DM) di dunia sekitar 415 juta dan akan diperkirakan menjadi 642 juta pada tahun 2040 (IDF, 2017). Dari 10 negara penyandang DM terbesar di dunia, Indonesia merupakan negara urutan ke 7 , yaitu sekitar 10 juta penduduk. Penyandang DM dengan umur $\geq 15$ tahun pada tahun 2018 sebanyak 2\%, data ini memperlihatkan peningkatan dari lima tahun sebelumnya sebesar 1,5\% di tahun 2013 (PERKENI,2019).

Menurut PERKENI,2015, diagnosis DM ditegakkan atas dasar pemeriksaan laboratorium yang dapat meliputi beberapa parameter pemeriksaan seperti pemeriksaan glukosa darah puasa, Tes Toleransi Glukosa Oral (TTGO), glukosa darah sewaktu, dan HbA1c dengan metode yang terstandarisasi oleh National Glycohaemoglobin Standarization Program (NGSP). Selain digunakan untuk menegakkan diagnosis DM, HbA1c juga digunakan untuk mengontrol keadaan glikemik pada pasien DM karena kadar HbA1c dapat memberikan gambaran rata-rata konsentrasi glukosa darah dalam periode 2-3 bulan (Zhou DT dkk, 2014 dan Widhyasih,R.M.,dan Nurshofi,S.E.2019). Pemeriksaan HbA1c memiliki kelebihan, yaitu tidak menuntut pasien untuk berpuasa dan hasil pemeriksaan pun tidak dipengaruhi oleh gaya hidup jangka pendek pasien, seperti makanan, minuman, dan aktivitas fisik (Primadana dkk., 2016).

Keadaan hiperglikemia kronis akibat DM yang tidak terkontrol berperan penting dalam inisiasi komplikasi, seperti nefropati diabetik, yang terjadi pada 40\% dari seluruh pasien DM tipe 1 dan DM tipe 2 (Rivandi dan Yonata, 2015; Kausik dan Umanath, 2018). Nefropati diabetik dapat disebabkan karena konsentrasi glukosa darah yang tidak terkontrol yang secara progresif menyebabkan ginjal harus bekerja lebih berat dalam menyaring darah (ADA, 2017). Menurut American Journal of Kidney Disease pada tahun 2018, nefropati diabetik ditandai dengan adanya keadaan mikroalbuminuria, yaitu ekskresi 
protein albumin ke urin lebih dari 30-300 mg per hari yang dapat berkembang menjadi keadaan makroalbuminuria, yaitu ekskresi albumin ke urin lebih dari $300 \mathrm{mg}$ per hari. Makroalbuminuria terjadi pada hampir seluruh pasien DM 5-10 tahun setelah terdiagnosis DM (Kausik dan Umanath, 2018). Apabila keadaan ini terus berkelanjutan, dapat menyebabkan sistem penyaringan ginjal rusak dan akan menyebabkan terjadinya penurunan fungsi ginjal yang dibuktikan dengan kenaikan konsentrasi serum kreatinin atau penurunan laju filtrasi glomerulus (LFG) dan dapat berakhir dengan kegagalan fungsi ginjal (Rivandi dan Yonata, 2015).

Parameter untuk mengetahui fungsi ginjal dan progresi penyakit nefropati diabetik salah satunya adalah dengan melihat nilai LFG. LFG diterima sebagai indeks terbaik dari keseluruhan fungsi ginjal, deteksi, dan tingkat keparahan penyakit ginjal. LFG menggunakan beberapa variabel dalam perhitungannya, yaitu kreatinin darah, umur, jenis kelamin, dan ras (NKD, 2014; Kausik dan Umanath, 2018).

Beberapa penelitian telah dilakukan untuk mengetahui korelasi antara kadar HbA1c dengan LFG. Penelitian Sukohar dkk. (2018) menyebutkan bahwa terdapat korelasi yang kuat antara kadar HbA1c dengan LFG pada pasien DM tipe 2 dengan nilai kemaknaan $(p)$ sebesar 0,000 $(p<0,005)$ dan nilai korelasi $(r)$ sebesar -0,748. Namun, penelitian lain yang dilakukan oleh Gahung dkk. (2016) menyebutkan bahwa tidak terdapat korelasi yang bermakna antara kadar HbA1C dengan LFG pada pasien DM tipe 2, ditunjukkan dengan $p=0,462$ dan $r=0,093$. Hal tersebut menunjukkan bahwa terdapat perbedaan pada hasil penelitianpenelitian yang ada tentang korelasi antara kadar HbA1c dengan LFG pada pasien DM. Tujuan dari penelitian ini adalah untuk melihat korelasi antara kadar HbA1c dan LFG pada pasien DM. 


\section{BAHAN DAN METODE}

Populasi penelitian ini adalah data seluruh pasien RSUD Budhi Asih penderita DM yang diperiksa kadar HbA1c dan kreatinin serum pada periode bulan Januari-Desember 2019. Sampel penelitian adalah data pasien DM yang memenuhi kriteria inklusi sesuai besar sampel yaitu 90 sampel. Sebagai variabel bebas adalah kadar HbA1c dan variabel terikat adalah nilai LFG. Kriteria inklusi adalah pasien DM yang melakukan pemeriksaan HbA1C dan kreatinin serum dengan jarak pemeriksaan tidak lebih dari 3 bulan dan telah menderita DM lebih dari 5 tahun. Kadar HbA1c dan kreatinin serum untuk menghitung LFG berdasarkan formula Modification of Diet in Renal Disease (MDRD) diperoleh dari LIS.

Penelitian ini menggunakan desain observasi analitik cross-sectional dengan menggunakan data rekam medis pasien DM di RSUD Budhi Asih periode Januari-Desember 2019. Penelitian dilakukan pada November 2019-Juli 2020. Pengambilan sampel dilakukan secara probability sampling dengan teknik pengambilan sampel SRS (Sample Random Sampling). Analisis data dilakukan secara deskriptif dan bivariat dengan uji korelasi. Kenormalan data di uji dengan Kolmogorov-Smirnov, diperoleh nilai $\mathrm{P}$ (Asymp. Sig) < nilai $\alpha(0,05)$ maka dapat disimpulkan bahwa distribusi data tidak normal, sehingga analisis data dilanjutkan dengan uji korelasi Spearman's. Blla data normal maka dilanjutkan uji korelasi Pearson's.

\section{HASIL}

Penelitian terhadap 90 data hasil pemeriksaan HbA1c dan kreatinin serum pasien dengan status klinis DM di RSUD Budhi Asih pada bulan Januari-Desember 2019. Selanjutnya, data kreatinin serum diolah menggunakan rumus MDRD, sehingga didapatkan hasil LFG. Gambaran deskriptif jenis kelamin, umur, kadar HbA1c, dan LFG dapat dilihat pada tabel 1. 
Tabel 1. Hasil Analisis Deskriptif

\begin{tabular}{|c|c|c|c|c|c|c|}
\hline & Variabel & $\mathbf{N}$ & $\%$ & Min & Maks & $\begin{array}{l}\text { Rata- } \\
\text { Rata }\end{array}$ \\
\hline \multirow{2}{*}{$\begin{array}{l}\text { Jenis } \\
\text { Kelamin }\end{array}$} & Laki-laki & 35 & 38,8 & & & \\
\hline & Perempuan & 55 & 61,1 & & & \\
\hline \multirow[t]{4}{*}{ Umur (tahun) } & Secara keseluruhan & 90 & & 33 & 81 & 58,1 \\
\hline & Menurut kategori & & & & & \\
\hline & $<45$ & 7 & 7,7 & & & \\
\hline & $\geq 45$ & 83 & 92,2 & & & \\
\hline \multicolumn{2}{|l|}{ HbA1c (\%) } & 90 & & 5,0 & 13,2 & 7,9 \\
\hline \multicolumn{2}{|c|}{ LFG $\left(\mathrm{mL} / \mathrm{min} / 1,73 \mathrm{~m}^{2}\right)$} & 90 & & 15 & 131 & 60 \\
\hline
\end{tabular}

Berdasarkan tabel 1, dari 90 data, terdapat 35 laki-laki $(38,8 \%)$ dan 55 perempuan $(61,1 \%)$. Umur subjek penelitian bervariasi dari 33 - 81 tahun dengan rata-rata 58,1 tahun. Subjek dengan kelompok umur < 45 tahun berjumlah 7 orang $(7,7 \%)$, dan kelompok umur $\geq 45$ tahun yaitu 83 orang $(92,2 \%)$. Hasil pemeriksaan HbA1c berkisar antara 5,0\% sampai $13,2 \%$ dengan rata-rata $7,9 \%$. Pada hasil perhitungan LFG, didapatkan nilai terendah $15 \mathrm{~mL} / \mathrm{min} / 1,73 \mathrm{~m}^{2}$, nilai tertinggi $131 \mathrm{~mL} / \mathrm{min} / 1,73 \mathrm{~m}^{2}$, dan rata-rata $60 \mathrm{~mL} / \mathrm{min} / 1,73 \mathrm{~m}^{2}$.

Tabel 2. Hasil Tabulasi Silang HbA1c dan LFG

\begin{tabular}{cccccccc}
\hline & \multicolumn{8}{c}{ LFG } \\
\cline { 2 - 8 } HbA1c (\%) & \multicolumn{2}{c}{$\begin{array}{c}\geq 0 \\
\mathrm{~mL} / \mathrm{min} / 1,73 \mathrm{~m}^{2}\end{array}$} & \multicolumn{2}{c}{$<\mathrm{mL} / \mathrm{min} / 1,73 \mathrm{~m}^{2}$} & \multicolumn{2}{c}{ Total } \\
\cline { 2 - 8 } & $\mathrm{n}$ & $\%$ & $\mathrm{n}$ & $\%$ & $\mathrm{n}$ & $\%$ \\
\hline $\begin{array}{c}\text { Kontrol Baik } \\
(<6,5)\end{array}$ & 5 & 5,5 & 10 & 11,1 & 15 & 16,6 \\
\hline $\begin{array}{c}\text { Kontrol Cukup } \\
(6,5-8)\end{array}$ & 1 & 1,1 & 40 & 44,4 & 41 & 45,5 \\
\hline $\begin{array}{c}\text { Kontrol Buruk } \\
(>8)\end{array}$ & 1 & 1,1 & 33 & 36,6 & 34 & 37,7 \\
\hline Total & 7 & 7,7 & 83 & 92,2 & 90 & 100,0 \\
\hline
\end{tabular}


Tabel 2 menunjukkan hasil tabulasi silang pemeriksaan HbA1c dan LFG pada pasien DM yang dijadikan responden penelitian. Dapat dilihat bahwa hasil HbA1c kontrol baik pada pasien dengan hasil $L F G \geq 90 \mathrm{ml} / \mathrm{min} / 1,73 \mathrm{~m}^{2}$ adalah sebanyak 5 orang $(5,5 \%)$ dan pasien dengan hasil LFG $<90 \mathrm{ml} / \mathrm{min} / 1,73 \mathrm{~m}^{2}$ adalah sebanyak 10 orang $(11,1 \%)$. Pada hasil HbA1c kelompok kontrol cukup, terdapat 1 orang $(1,1 \%)$ pasien dengan hasil LFG $\geq 90 \mathrm{ml} / \mathrm{min} / 1,73 \mathrm{~m}^{2}$ dan 40 orang $(44,4 \%)$ dengan hasil $L F G<90 \mathrm{ml} / \mathrm{min} / 1,73 \mathrm{~m}^{2}$. Sedangkan pada hasil HbA1c kelompok kontrol buruk, terdapat 1 orang $(1,1 \%)$ dengan hasil LFG $\geq 90$ $\mathrm{ml} / \mathrm{min} / 1,73 \mathrm{~m}^{2}$ dan 33 orang $(36,6 \%)$ dengan nilai LFG $<90 \mathrm{ml} / \mathrm{min} / 1,73 \mathrm{~m}^{2}$.

Tabel 3. Hasil Uji Normalitas Data dan Perhitungan Korelasi antara Kadar HbA1c dan LFG

\begin{tabular}{|c|c|c|c|c|c|}
\hline & \multicolumn{2}{|c|}{$\begin{array}{l}\text { Uji Normalitas Data } \\
\text { Kolmogorov-Smirnov }\end{array}$} & \multicolumn{3}{|c|}{$\begin{array}{l}\text { Uji Korelasi } \\
\text { Spearman's }\end{array}$} \\
\hline & $\mathrm{n}$ & Sig. & $\mathrm{n}$ & Sig. & $\begin{array}{l}\text { Koefisien } \\
\text { Korelasi }\end{array}$ \\
\hline HbA1c & 90 & 0,022 & 90 & 0,000 & $-0,396$ \\
\hline LFG & 90 & 0,200 & 90 & & \\
\hline
\end{tabular}

Dari hasil uji Kolmogorov-Smirnov, diperoleh nilai P (Asymp. Sig) < nilai $\alpha$ $(0,05)$, disimpulkan bahwa distribusi data tidak normal, sehingga dilanjutkan dengan uji korelasi Spearman's. Hasil uji Spearman's, dengan tingkat kepercayaan 95\% dengan nilai $\alpha 0,05$, didapat nilai sig. 0,000 $<0,05$ yang berarti terdapat korelasi antara kadar HbA1c dan LFG pada pasien DM dengan nilai koefisien korelasi $r=-0,396$ (korelasi sedang). Hasil tersebut menggambarkan semakin tinggi kadar HbA1c dalam darah maka semakin semakin rendah nilai LFG. Kadar HbA1c yang >8\% menunjukkan kontrol glikemik yang tidak baik dan LFG $<90 \mathrm{~mL} / \mathrm{min} / 1,73 \mathrm{~m}^{2}$ mengindikasikan fungsi ginjal yang mulai menurun. 


\section{DISKUSI}

Berdasarkan 90 data rekam medis pasien diabetes melitus periode Januari sampai Desember 2019 di RSUD Budhi Asih dengan lama menderita DM lebih dari 5 tahun. Jumlah pasien perempuan penderita DM yang lebih tinggi dari laki-laki dapat disebabkan karena berbagai faktor seperti sindrom premenstrual, kenaikan Indeks Massa Tubuh (IMT), dan menopause. Setelah menopause, terdapat kemungkinan terjadinya perubahan hormon, terutama hormon estrogen dan progesteron yang mempengaruhi kadar glukosa darah dan merangsang kenaikan jumlah lemak abdomen serta lemak tubuh total. Kelebihan lemak tubuh juga diasosiasikan dengan kenaikan risiko terjadinya penyakit metabolik (Sugondo dan Alexander,T. 2019 dan Widhyasih, R.M.,dan Nurshofi, S.E. 2019).

Sebanyak 83 orang $(92,2 \%)$ dari total pasien penderita DM berumur $\geq 45$ tahun. Hal tersebut sesuai pernyataan dari Indonesian Endocrinology Association bahwa orang yang berumur $\geq 45$ tahun dianjurkan untuk melakukan pemerikasan DM karena risiko untuk menderita intoleransi glukosa akan mulai meningkat seiring dengan bertambahnya umur

Kadar glukosa darah pada pasien DM yang tidak terkontrol dan waktu menderita diabetes yang cukup lama akan meningkatkan risiko komplikasi mikrovaskular seperti risiko penurunan fungsi ginjal yang akan mengarah pada kejadian nefropati diabetik (Kowalski, A. dkk, 2015). Kadar glukosa darah yang tinggi dapat menyebabkan terjadinya interaksi antara faktor hemodinamik dan metabolik. Pada faktor metabolik, terjadi metabolisme glukosa yang tidak normal, sedangkan di faktor hemodinamik, terjadi reaksi angiotensin II yang merupakan hormon vasoaktif. Kedua faktor tersebut menyebabkan kaskade dalam pengaktifan sitokin-sitokin intraseluler yang pada akhirnya akan merangsang reaksi sitokin lain yang akan menstimulasi pembentukan 
fibrinosetin dan kolagen. Hal tersebut akan berakhir pada peningkatan tekanan intrarenal, kenaikan permeabilitas vaskular, proteinuria, dan menurunnya laju filtrasi glomerulus (LFG) (Sukohar dkk., 2018).

Kontrol glikemik yang tidak terkontrol akan menyebabkan tingginya kadar HbA1c dalam darah dan pada akhirnya dapat menyebabkan penurunan LFG yang merupakan pertanda adanya kerusakan ginjal. Hasil penelitian pada tabel 1 menunjukkan bahwa rata-rata kadar HbA1c pada subjek penelitian adalah 7,9\%. Kadar HbA1C $>7.0 \%$ berhubungan dengan peningkatan risiko yang signifikan terjadinya komplikasi mikrovaskuler dan makrovaskuler. Selain itu, rata-rata LFG pada subjek penelitian adalah $60 \mathrm{~mL} / \mathrm{min} / 1,73 \mathrm{~m}^{2}$. Hal ini menunjukan bahwa sebagian besar pasien mengalami penurunan LFG dan menurut tahapan penyakit ginjal yang ditetapkan oleh National Kidney Foundation (2013), hasil ini menunjukan adanya kerusakan ginjal tahap 2 dengan penurunan LFG ringan. Dari hasil tersebut, dapat dikatakan bahwa sebagian besar subjek penelitian memiliki kontrol glikemik kurang baik dan memiliki kemungkinan untuk mengarah kepada nefropati diabetik. Perlu dilakukan evaluasi agar keadaan tersebut tidak memburuk dan komplikasi pada ginjal dapat dicegah.

Dari hasil tabulasi silang pada tabel 2, dapat diketahui bahwa hanya sedikit pasien DM dengan kontrol HbA1c yang baik, yaitu sebanyak 16,6\%. Berdasarkan tabel 3, hasil penelitian menunjukkan bahwa terdapat korelasi sedang antara HbA1C dan LFG dengan nilai koefisien korelasi ( $r$ ) sebesar -0,396 pada tingkat kepercayaan $95 \%$ dengan nilai $\alpha 0,05$. Korelasi yang ditunjukkan adalah korelasi negatif yang berarti semakin tinggi kadar HbA1c maka semakin rendah kadar LFG. Penelitian lain tentang korelasi antara kadar HbA1c dengan LFG yang dilakukan oleh Sugondo dan Alexander,T. (2019) pada pasien DM juga menunjukan hasil serupa dengan koefisien korelasi masing-masing sebesar 0,341 dan $-0,784$ pada $\alpha=0,05$. Selain itu, terdapat penelitian lain yang sejalan dengan penelitian ini, yaitu penelitian yang dilakukan oleh Kumar dkk (2014) 
yang menyatakan bahwa ada korelasi yang bermakna antara nilai HbA1c dengan LFG pada pasien DM yang diukur menggunakan nilai kreatinin serum dengan persamaan MDRD.

Penelitian yang dilakukan oleh Rigalleau dkk. pada tahun 2006 melaporkan adanya korelasi yang signifikan antara nilai HbA1c dan nilai LFG pada pasien DM tipe 2. Penelitian ini juga melaporkan bahwa formula MDRD yang digunakan untuk menghitung nilai LFG memiliki akurasi yang lebih baik dibanding formula lain, seperti formula Cockcroft-Gault dalam mengukur estimasi laju filtrasi glomerulus (Dewi,Y.P.2015). Selain ini, penelitian yang dilakukan Takenouchi dkk.(2015) mengatakan bahwa ada hubungan antara peningkatan nilai HbA1c dengan penurunan LFG pada pasien DM tipe 2. Penelitian yang sama juga melaporkan bahwa penurunan LFG terjadi lebih banyak pada pasien DM tipe 2 dengan pola makan yang tidak terkontrol (Gahung, Rixi Y. dkk. (2016).

Peningkatan LFG yang terjadi dalam kondisi hiperglikemia disebabkan karena ada hiperfiltrasi glomerulus pada tahap awal keterlibatan ginjal pasien DM, setelah ditangani dan mendapat pengobatan yang tepat selama beberapa bulan, HbA1c akan mengalami penurunan yang akan berimbas kepada penurunan LFG yang cukup bermakna. HbA1c sebagai tolok ukur status pengendalian glikemik dapat dipakai sebagai biomarker yang berguna untuk mengidentifikasi kemunculan kebahayaan kardiovaskular dan penyakit ginjal di populasi umum. Hiperglikemia dapat meningkatkan hiperfiltrasi glomerulus yang akan menambah koefisien ultrafiltrasi dan permeabilitas terhadap dekstran kecil. Di samping itu juga akan menyebabkan deposisi berlebihan protein ekstrasel, perluasan jaringan oleh faktor pertumbuhan, sklerosis glomerulus, dan berujung pada penurunan LFG (Amiroh dan Tahono, 2015).

Terlepas dari hasil penelitian yang menunjukan adanya korelasi antara kenaikan HbA1c dan penurunan LFG, hasil tabulasi silang pada tabel 2 menunjukkan bahwa terdapat sejumlah pasien dengan kontrol HbA1c baik namun diiringi dengan nilai $L F G<90 \mathrm{~mL} / \mathrm{min} / 1,73 \mathrm{~m}^{2}$, yaitu sejumlah 10 pasien $(11,1 \%)$. Hal ini dapat disebabkan karena adanya kemungkinan penurunan fungsi 
ginjal akibat gangguan ginjal selain nefropati diabetik atau adanya komplikasi dari keadaan klinis pasien lainnya. Kemungkinan tersebut sejalan dengan penelitian yang dilakukan oleh Wen Hu (2015) bahwa kerusakan ginjal bisa terjadi sebelum pasien menderita hiperglikemia. Selain itu, efek dari pemakaian obat-obatan hipertensi seperti Renin-Angiotensis-Aldosterone System (RAAS) Inhibitor juga dapat menurunkan laju filtrasi glomerulus (Weil dkk, 2019).

Penelitian ini memiliki beberapa keterbatasan, yaitu tidak ada data-data pendukung seperti data IMT pasien, penyakit lainnya yang mungkin diderita, gaya hidup, penggunaan obat-obatan, kepatuhan kontrol glikemik, dan diet pasien yang mungkin dapat lebih menjelaskan kondisi glikemik dan keadaan fungsi ginjal. Keterbatasan-keterbatasan tersebut di luar kendali peneliti.

\section{KESIMPULAN}

Hasil rata-rata kadar HbA1c pada pasien DM di RSUD Budhi Asih Jakarta Timur pada tahun 2019 adalah 7,9\% yang berarti sebagian besar pasien memiliki tingkat kontrol HbA1C yang harus diwaspadai. Hal ini mencerminkan pengendalian metabolisme glukosa selama 3 bulan yang tidak baik dari pasien. Hasil rata-rata nilai laju filtrasi glomerulus (LFG) adalah $60,0 \mathrm{ml} / \mathrm{min} / 1,73 \mathrm{~m}^{2}$ yang diartikan bahwa sebagian besar pasien memiliki nilai LFG $<90$ $\mathrm{ml} / \mathrm{min} / 1,73 \mathrm{~m}^{2}$ dan mengindikasikan adanya penurunan pada fungsi ginjal. Hasil uji korelasi Spearman antara kadar HbA1c dengan LFG ( $p$ value $=0,000$ ) dengan arah korelasi negatif $(r=-0,396)$ Hasil tersebut menggambarkan semakin tinggi kadar HbA1c dalam darah maka semakin semakin rendah nilai LFG. Kadar HbA1c yang > $\%$ menunjukkan kontrol glikemik yang tidak baik dan LFG $<90 \mathrm{~mL} / \mathrm{min} / 1,73 \mathrm{~m}^{2}$ mengindikasikan fungsi ginjal yang mulai menurun. 


\section{UCAPAN TERIMAKASIH}

Kami berterima kasih kepada pihak-pihak yang membantu pelaksanaan penelitian ini juga terima kasih kepada RSUD Budhi Asih yang telah memfasilitasi pengambilan data dari penelitian kami.

\section{KONFLIK KEPENTINGAN}

Tidak ada konflik kepentingan dalam penelitian ini.

\section{REFERENSI}

ADA. (2017). Living with Diabetes: Complication (http: / / www.diabetes.org/living-with-diabetes/complications/kidneydisease-nephropathy.html). Diakses pada 22 April 2019.

Amiroh dan Tahono. (2015). Angka Banding Albumin Kreatinin Air Kemih dan HbA1c serta Estimasi Laju Filtrasi Glomerulus pada Pasien Diabetes Melitus Tipe 2. Indonesian Journal of Clinical Pathology and Medical Laboratory. Vol. 21 No. 3. Hlm. 250-256.

Dewi, Y.Puspa.(2015). Performa Formula Cockcroft-Gault, MDRD, dan CKD-EPI. Penelitian Stase. Yogyakarta: Fakultas Kedokteran Universitas Gadjah Mada.

Gahung, Rixi Y. dkk. (2016). Hubungan Kadar HbA1C dengan Estimasi Filtrasi Glomerulus pada Pasien DM Tipe 2. Jurnal e-Clinic. Edisi Januari-Juni 2016 Vol 4 No 1.

Hu, Wen dkk. (2015). Association of Elevated Glycosylated Hemoglobin A1c with Hyperfiltration in A Middle-aged and Elderly Chinese Population with Prediabetes or Newly Diagnosed Diabetes: A Cross-Sectional Study. BMC Endocrine Disorder: 15(47).

International Diabetes Federation. (2017). Diabetes Atlas 8th Edition (https://www.diabetesatlas.org/across-the-globe.html). Diakses pada 23 April 2019.

IDF. (2017). What Is Diabetes (https://www.idf.org/aboutdiabetes/what-isdiabetes.html). Diakses pada 23 April 2019. 
Kausik dan Umanath,(2018).Update on Diabetic Nephropathy: Core Curriculum 2018. American Journal of Kidney Disease. Vol. 71. Issue 6.

Kowalski, A. dkk. (2015). Diabetes and Chronic Kidney Disease. Disease-aMonth, 61(9), hlm. 378-386.

Kumar, Sanjeev dkk. (2014). Correlation of Diabetic Nephropathy and HbA1C in Newly Diagnosed Type 2 Diabetic Patients of Western UP. International Journal of Scientific and Research Publications: 4(12):3-6.

National Kidney Foundation. (2014). Frequently Asked Questions About GFR estimates. Jurnal Kidney.org.

PERKENI. (2015). Konsensus Pengelolaan dan Pencegahan Diabetes Melitus Tipe 2 di Indonesia. Jakarta: PB PERKENI.

PERKENI. (2019). Pedoman Pemantauan Glukosa Darah Mandiri. Jakarta: PB PERKENI.

Primadana, Pandelaki dan Wongkar. (2016). Hubungan Kadar HbA1c dengan Profil Lipid pada Pasien Kaki Diabetik di RSUP Prof. Dr. R. D. Kandou Manado. Jurnal e-Clinic. Edisi Januari-Juni 2016. Vol. 4. No. 1: 134-139.

Rivandi dan Yonata, Ade. (2015). Majority: Hubungan Diabetes Melitus dengan Kejadian Gagal Ginjal Kronik. Fakultas Kedokteran Universitas Lampung. Edisi Desember 2015 Vol 4 No 9: 28.

Sukohar, Damara, Airlangga. (2018). Hubungan Nilai Hba1c dengan Laju Filtrasi Glomerulus (LFG) pada Pasien Diabetes Melitus Tipe 2 di Rumah Sakit Umum Daerah H. Abdul Moeloek Bandar Lampung. Skripsi. Fakultas Kedokteran Universitas Lampung. Lampung.

Sugondo dan Alexander T. dkk. (2019). Relationship Between HbA1c Levels with Egfr and Blood Pressure in Type 2 Diabetes Mellitus Patients at General Hospital in Surabaya. Biomolecular and Health Science Journal. Vol 2 (02): 118.

Takenouchi, Akiko dkk. (2015). Direct Association of Visit-to-visit HbA1c Variation with Annual Decline in Estimated Glomerular Filtration Rate in Patients with Type 2 Diabetes. Journal of Diabetes \& Metabolic Disorders: 14(69):1-7.

Weil, E. Jennifer dkk. (2019). Glycemia Affects Glomerular Filtration Rate in People with Type 2 Diabetes. BMD Nephrology: 20(397).

Widhyasih, R.M., dan Nurshofi, S.E. (2019). HbA1c as Glycemic Control is Associated with Triglycerides Levels in Type 2 Diabetes Mellitus. DOI:10.2291/ichs-18.2019.31 
Zhou, D.T., dkk. (2014). Significant Differences in the Prevalence of Elevated HbA1C Levels for Type I and Type II Diabetics Attending the Parirenyatwa Diabetic Clinic in Harare, Zimbabwe. Chin J Biology. 